九州大学学術情報リポジトリ

Kyushu University Institutional Repository

\title{
Current Situation and Future Scope of Biomass Gasification in Japan
}

\section{Furutani, Yuki}

Interdisciplinary Graduate School of Engineering Sciences, Kyushu University

Norinaga, Koyo

Graduate School of Engineering, Nagoya University

Kudo, Shinji

Institute for Materials Chemistry and Engineering, Kyushu University

Hayashi, Jun-ichiro

Institute for Materials Chemistry and Engineering, Kyushu University | Research and Education Centre of Carbon Resources, Kyushu University

他

https://doi.org/10.5109/1929681

出版情報: Evergreen. 4 (4)，pp.24-29，2017-12. 九州大学グリーンアジア国際リーダー教育センター バージョン：

権利関係 : 


\title{
Current Situation and Future Scope of Biomass Gasification in Japan
}

\author{
Yuki Furutani ${ }^{1, *}$, Koyo Norinaga ${ }^{2}$, Shinji Kudo ${ }^{3}$, \\ Jun-ichiro Hayashi, ${ }^{3,4}$, Tomoaki Watanabe ${ }^{5}$ \\ ${ }^{1}$ Interdisciplinary Graduate School of Engineering Sciences, Kyushu University, Japan \\ ${ }^{2}$ Graduate School of Engineering, Nagoya University, Japan \\ ${ }^{3}$ Institute for Materials Chemistry and Engineering, Kyushu University, Japan \\ ${ }^{4}$ Research and Education Centre of Carbon Resources, Kyushu University, Japan \\ ${ }^{5}$ Advanced Graduate Program in Global Strategy for Green Asia, Kyushu University \\ *Author to whom correspondence should be addressed, \\ E-mail: 3ES15008R@s.kyushu-u.ac.jp
}

(Received August 18, 2017; accepted October 16, 2017).

In this study, we investigated current situation of biomass gasification plants in 5 cities (c.a. Murayama City, Chichibu City, Ueno Village, Oshu City and Yamaguchi City) in Japan, and make R\&D policy proposals to expand the biomass gasification plants. Four cities have commonly promoted the efficient heat utilization such as snow melting, drying the wood and supplying hot water into mushroom bed and hot spring. However, heat utilization is limited in a small area because heat loss is generated during the long-distance transportation. In order to obtain energy forms suitable for the long-distance transportation, such as hydrogen gas and electricity, the R\&D of biomass gasification with hydrogen production or combined with Solid Oxide Fuel Cell (SOFC) should be promoted in the future.

Keywords: biomass gasification, CHP, hydrogen energy.

\section{Introduction}

Ever since the industrial revolution, humanity has consumed a huge amount of energy and thus global energy demand in 2040 is predicted to increase $37 \%$ higher than the current level ${ }^{1)}$. This massive energy consumption has caused various issues such as climate change, greenhouse gas emissions and the depletion problem of fossil fuels. ${ }^{2)}$ As a result, recently the interest in renewable energy is increasing, and in particular

Table 1: Biomass process technology options classification. ${ }^{4)}$

\begin{tabular}{lll}
\hline Conversion process & Final products & Advantages \\
\hline Direct combustion & Steam & Most often-used conversion process \\
& $\begin{array}{l}\text { Heat } \\
\text { Electric energy }\end{array}$ & \\
& & \\
Biochemical & Bioethanol & Useful method for moisture content biomass \\
& Biogas & \\
Agrochemical & Biodiesel & Simple production process \\
& Steam & High efficiency using combined-cycle gas turbine systems \\
Gasification & Heat & \\
& Electric energy & \\
& Fuel gas & \\
Pyrolysis & Char-coal & Conversion to various types of fuels \\
& Fuel gas & \\
& Bio-oil & \\
\hline
\end{tabular}


biomass utilization has received broad attention due to its $\mathrm{CO}_{2}$ neutral property. Currently, the percentage of biomass energy in world's total primary energy consumption is approximately $10 \%$, and this will be increased especially in developing countries during the next 30 years $^{3)}$.

Advantage of biomass utilization is that biomass resources can be used in various types of energy application, including electric and heat generation for industrial facilities and homes. Biomass conversion technologies to such useful energies can be separated into four process technologies: direct combustion process technology, biochemical process technology, agrochemical process technology and thermochemical process technology. ${ }^{4)}$ The final energy products and the advantages of these process technologies were listed in Table 1. Direct combustion technology is the main process to convert biomass resources into heat, mechanical power and electricity. This system is available in the size range from a few MW up to more than $100 \mathrm{MW}^{5}$. Biochemical processes, using fermentation, converts biomass into biological hydrogen gas and ethanol via acid/enzymatic hydrolysis. Biomass resources with high-moisture content, such as the herbaceous plant sugarcane, are more economically suited to biochemical process which is 'wet/aqueous' conversion $^{6}$. Agrochemical processes are the mechanical extraction method to produce bio-diesel energy form. For instance, bio-diesel is directly extracted by crushing seed crops containing a high percentage of oil $^{7,8)}$. Thermochemical processes are able to be subdivided into gasification and pyrolysis. Gasification converts biomass with a low moisture content (e.g. wood chips) into syngas products, such as hydrogen $\left(\mathrm{H}_{2}\right)$, carbon monoxide (CO) and methane $\left(\mathrm{CH}_{4}\right)$. The syngas is converted into both electricity and heat in gas engine. Biomass gasification has been developed commercially owing to two main factors: a higher level of electricity and heat generation efficiency even in small-scale plant, and a lower level of exhaust emissions of major air pollutants. Pyrolysis is the thermochemical conversion process in absence of air to produce a bio-oil, a charcoal and a syngas.

In Japan, various types of research and development (R\&D) related with biomass utilization has been performed owing to the oil crisis in the 1970s. In the trend of bioenergy utilization, the Japanese government has developed several strategies for biomass utilization in Japan. In June 2002, a committee was established to develop the strategies, and half a year later "Biomass Nippon Strategy9)"' was developed by the cabinet. The goal of this strategy was to expand biomass utilization and develop the relating technologies. The strategy mentions the four reasons to promote biomass utilization: (1) creation of a regional employment, (2) activation of forestry, fishery, and agriculture industries, (3) reduction of greenhouse gas emission, and (4) fostering and promotion of venture companies.

The biomass utilization has been promoted by developing "Biomass Nippon Strategy”, increasing R\&D funds, and easing various regulations. However, a big barrier toward the expansion of biomass utilization is that the amount of practically available biomass resource is predicted to account for only $5 \%$ of total primary energy supply in Japan ${ }^{10}$ ). Thus, the idea is needed for small-scale utilization suitable for scare biomass resources. Biomass gasification has attracted the most attention because this process can be operated with high efficiency even in small-scale plant ${ }^{11)}$. Biomass gasification seems to be suitable as a decentralized and small-scale region like Japan. In this study, we investigated current situation of biomass gasification plants (e.g. gasifier types and heat utilization), and make policy proposals to create the technological innovations

Table 2: Biomass gasification plant in Japan ${ }^{12)}$.

\begin{tabular}{llll}
\hline Company & Gasifier type & Location & Capacity [kW] \\
\hline Takuma Co.,Ltd & Circulating fluidized bed & Misato City, Saitama & 200 \\
Kawasaki Heavy Industries, Ltd. & Fluid bed & Niyodogawa Town, Kochi & 150 \\
Burkhardt & & & 165 \\
JFE Engineering Corporation & Up-draft & Ueno Village, Gunma & 2000 \\
& & Murayama City, Yamagata & 2000 \\
TSUKISHIMA KIKAI CO.,LTD. Down-draft & Ishikawa City, Ishikawa & 115 \\
& & & 360 \\
Yanmar Holdings Co., Ltd. & Down-draft & Chichibu City, Saitama & \\
& & Senboku City, Akita & 35 \\
& & Oshu City, Iwate & 35 \\
& & Koshu City, Yamanashi & \\
Chugai Ro Co., Ltd. & & & 180 \\
& & Aso City, Kumamoto & 180 \\
& & Iwakuni City, Yamaguchi & 176 \\
& & Yamaguchi City, Yamaguchi & 170 \\
& & Sakai City, Osaka & 15 \\
& & Takayama City, Gifu & 50 \\
\hline
\end{tabular}


and to expand the biomass gasification plants in Japan.

\section{Biomass gasification plants in Japan}

Table 2 lists biomass gasification plants in $\mathrm{Japan}^{12)}$. According to table 2, various types of gasifier has been introduced and the electric capacities in the gasification plants are in the range of $10 \mathrm{~kW}$ to $2000 \mathrm{~kW}$. Here, we investigated current situation of biomass gasification plants in 5 cities (c.a. Murayama City, Chichibu City, Ueno Village, Oshu City and Yamaguchi City) in which different types of gasifiers, such as up-draft, down draft and rotary kiln types, has been introduced. We selected these 5 cities to examine the effect of gasifier types on the operational situation and heat utilization in each cities. Furthermore, we discussed keys toward successful operation of biomass gasification.

\subsection{Murayama City, Yamagata}

The gasifier used in Murayama city is up-draft type (see Fig. 1) having a higher efficiency. In this gasifier, the biomass fuel falls from the top zone of the reactor, and the oxygen or air is inserted into the bottom zone. The fuel slowly comes down by gravity and passes sequentially through drying (moisture evaporation), pyrolysis (release of a solid char residual and volatiles such as gases and aromatic compounds), reduction and oxidation zones (heterogeneous reactions of char with $\mathrm{O}_{2}$, $\mathrm{CO}_{2}, \mathrm{H}_{2} \mathrm{O}$ ). Simultaneously, the generated volatiles is carried upward along with the up flow of heated gas products. Ashes as the solid remains are removed at the bottom of the gasifier. The tars with aromatic compounds in the volatiles come out from the reactor along with the gas products. The up-draft gasifier generates high tar content, which accounts for up to $20 \%$ of the pyrolysis products, and thus requires substantial clean-up to remove this tar. The updraft gasifier can handle fuels in the particle size range of $5-100 \mathrm{~mm}$ and containing much amount of moisture; thus, it is suitable for a wide variety of fuel sizes and moisture content. In contrast to the downdraft gasifier, there is no upper limitation with respect to the size. There are two main advantages of updraft gasifiers: the high thermal efficiency and simple construction.

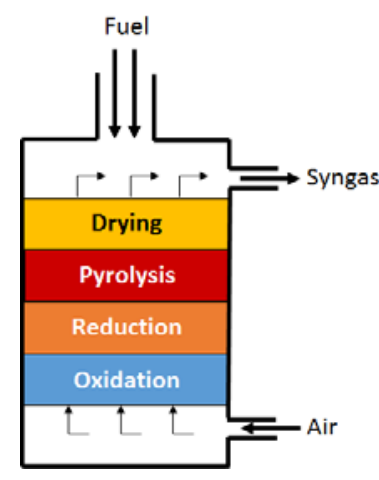

Fig. 1: Up-draft type gasifier
The capacity of the gasification plant in Murayama city is $2000 \mathrm{~kW}$, which is larger scale compared to the other types of plants as shown in Table 1 . This plant supplies electricity and heat to 11 communal facilities such as hospital, school and so on. In Yamagata there is much amount of biomass resource $(130,000 \text { Tone })^{13)}$ and especially fruit trees such as cherry, apple, pear accounts $(39,000 \text { Tone })^{13)}$, thus the gasification plant is available for input of $60 \mathrm{t} /$ day. This gasification plant has been operated by Yamagata Green Power Corporation and financed from local farming community. Although the disadvantage of up-draft gasifier is high content of tar in the syngas, the generated tar is effectively used as heavy oil. In Murayama city, there is a lot of snow in winter. In the future, heat generated from biomass gasification is expected to be utilized for snow melting ${ }^{14)}$.

\subsection{Chichibu City, Saitama}

Chichibu city has used the down-draft type gasification plant (see Fig. 2) available for input of 1.5 $\mathrm{t} /$ day $^{15)}$, which was smaller than that of Murayama city. Chichibu city installed the down-draft type due to its feature of a very small tar generation.

The down-draft type gasifier was originally developed to gasify high volatile fuels. The fuel is carried out into the top zone of the reactor and the gases flow concurrently with descending packed bed of solids. In the middle section of oxidation zone, the oxygen or air/steam is inserted. The volatile products are intimately mixed with char solids in the turbulent high-temperature oxidation region around throat, and thus the tar cracking occur mostly in this high-temperature region. In the bottom, there is a system to recover the solid product, such as the ash and char. The feature of fixed bed down-draft type gasification is reliable process due to a high conversion of the pyrolysis tars and hence producing relatively clean gases. This configuration is favored for fuels containing more than $25 \mathrm{wt} \%$ moisture and a low proportion of coarse and fine particles, preferably particle size range of $10-300 \mathrm{~mm}$. This gasification is generally suitable for small-scale electricity generation, owing to the low content of tars. Because the particle size and throat diameter is limited physically, the maximum capacity of this configuration is approximately $500 \mathrm{KW}_{\mathrm{e}}$.

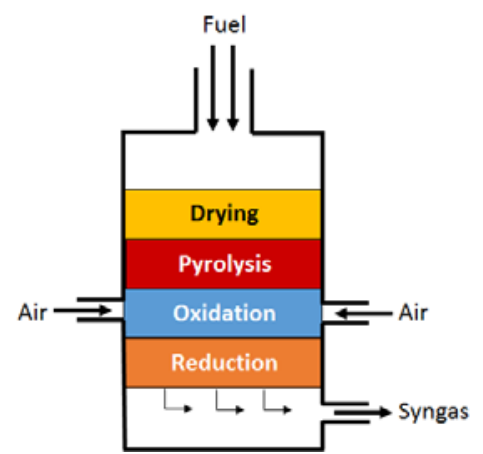

Fig. 2: Down-draft type gasifier 
The biomass gasification plant was operated by Chichibu city government and the generated electricity was supplied to the destination such as hotel, leisure facility, and so on. However, this plant was stopped in 2015 due to the fire disaster, and the resumption of operation is not planned ${ }^{15)}$.

\subsection{Ueno Village, Gunma}

Ueno Kinoko Center Corporation produces 500 tons/year of Chinese Mushroom, and creates an estimated 60 jobs $^{16)}$. For Chinese Mushroom production, the room temperature in the facility was needed to be maintained at $20^{\circ} \mathrm{C}$, and thus the heating and cooling system operated by electricity supplied large amount of heat to adjust the room temperature. However, electricity prices has been increased since the Great East Japan Earthquake of March 11 in 2011. As a result, biomass gasification plant with combined heat and power (CHP) manufactured by Burkhardt Company in Germany was introduced into this village. This gasifier is up-draft type with $165 \mathrm{~kW}$.

Heat has been mainly utilized for mushroom bed and air-conditioning equipment. Before the introduction of the biomass gasification plant, a hot-water boiler using a waste mushroom as a fuel (350 kW) and an electrical heating and cooling system (cooling capacity: 1,210 kW, and heating capacity: $1,540 \mathrm{~kW}$ ) had been utilized for heat supply ${ }^{16)}$. After the introduction of biomass gasification with CHP suppling hot water, the operating rate of the electrical heating and cooling system has been cut leading to the reduction of electrical utilization.

\subsection{Yamaguchi City, Yamaguchi}

Yamaguchi city installed rotary kiln gasifier (as illustrated in Fig. 3) to produce high quality of gases. Rotary kilns contain a slowly rotating cylindrical chamber. The contact between gases and solid occurs owing to the rotation of the drum. The heat and matter are not very effectively exchanged between the solid and the gases, and thus the longer reaction time is required compared with the other gasification technologies. The contact between solid and gases contact might be improved by introducing several barriers inside the drum, which handles the solid material more effectively and increases the contact area with the gas phase. The most general type is countercurrent type, where biomass fuel is inserted into the top of the reactor and the oxidizing agent into the bottom side. The main advantage of rotary kiln gasifier is providing gas of sufficiently high quality.

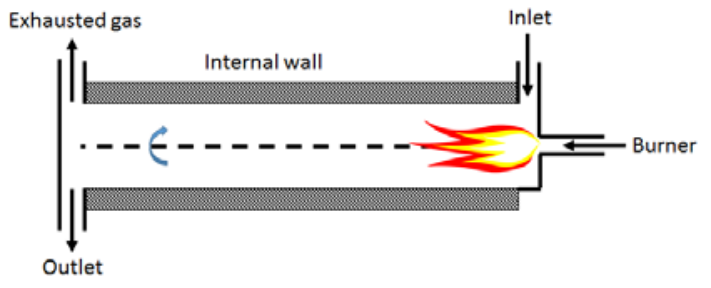

Fig. 3: Rotary kiln type gasifier
Biomass rotary kiln gasification plant $(25-100 \mathrm{~kW})$ is set in sawmill, and was built by Chugai Ro Corporation for the first time in Japan. Not only timbers from forest thinning such as Japanese cedar, cypress and bamboo but also residue generated in the sawmill are chipped and used as a biomass fuel. 5.0 tons / day has been supplied into the gasifier (rotary kiln), and the generated syngas has been converted into electricity (180 kWh) and heat in gas engine ${ }^{17)}$. Heat has been used to dry the wood in sawmill.

\subsection{Oshu City, Iwate}

In order to promote the regional activation in Oshu city in Iwate, biomass gasification plant with CHP was built in March, 2010. The gasifier is small-scale down-draft type $(35 \mathrm{~kW})$ with the low production of $\operatorname{tar}^{18)}$. Heat and power generated with CHP are effectively utilized in facility of Kurotaki Hot Springs. The introduction of the gasification plant reduces the cost of electric power by $50 \%$ and of heating oil by $30 \%$.

Although in Chichibu city the biomass gasification plant has already been stopped, the gasification plants in Murayama city, Ueno village, Yamaguchi city and Oshu city were successfully operated. These four cities have commonly promoted the effective heat utilization such as snow melting, drying the wood and supplying hot water into mushroom bed and hot spring. In order to expand biomass gasification all over Japan, not only heat utilization for local area but other utilization should be considered.

\section{Future prospect of biomass gasification in Japan}

As described previously, heat utilization improves the total efficiency and leads to the successful operation. However, heat loss is generated during the long-distance transportation, and thus heat utilization is limited to the surrounding area. In order to overcome this problem and expand biomass gasification in Japan, it is argued that two technologies, biomass gasification with hydrogen production and SOFC will be crucial in the future. In the following section, we examine the current situation on these technologies.

\subsection{Biomass gasification for hydrogen society}

The "hydrogen economy" has been paid attention due to sustainable, stockable and transportable properties. Japanese government aims to establish the hydrogen infrastructure in Tokyo by 2020. Biomass resource is expected to be utilized as one of the most important sources producing hydrogen gas. In Toshu city in Fukuoka, biomass gasification plant for producing hydrogen gas has been operated since 2011, and has handled biomass feedstocks of $847 \mathrm{~kg} /$ day $^{19)}$.

The hydrogen gas obtained by biomass gasification is relatively expensive compared with natural gas steam 
reforming. In renewable energy, on the other hand, biomass gasification is the most cost-effective process producing hydrogen gas.

Hydrogen gas can be produced combining the gasifier and steam reforming process as shown in Fig. 4. One of the big problems in biomass gasification producing hydrogen gas is the generation of tar formed during the process. The tar may cause deactivation of Ni catalyst used in steam reforming. The operation conditions, such as temperature, reaction time and percentage of gasifying agent should be optimized to reduce the tar formation ${ }^{20}$. Therefore, further research is needed to overcome the problem of tar formation.

Additionally, we must overcome a lot of social and economic problems, such as a lack of international visibility, a small market, a hydrogen gas utilization regulation, and so on. ${ }^{21)}$

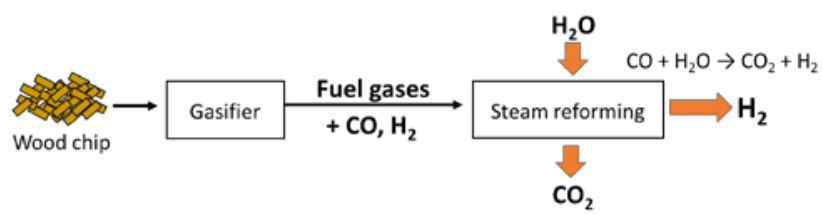

Fig. 4: Biomass gasification process for producing hydrogen gas.

\subsection{Biomass gasification with solid oxide fuel cell}

The gas engine cannot achieve high electrical efficiency in small-scale gasifier systems. In order to increase the electricity output from the gasification process, the gas engine should be replaced with a Solid Oxide Fuel Cell (SOFC) as shown in Fig. 5. However, this replacement means that the gasifiers must reduce the tar formation and provide gas of sufficiently high quality because tar impurities cause the clogging in SOFC system $^{22)}$. $\mathrm{CO}$ as well as $\mathrm{H}_{2}$ generated from the gasifier can be directly converted to the electricity output in a SOFC if the tar impurities in the gas is sufficiently reduced. Therefore, further $\mathrm{R} \& \mathrm{D}$ is needed to develop the gasifier providing gas of sufficiently high quality.

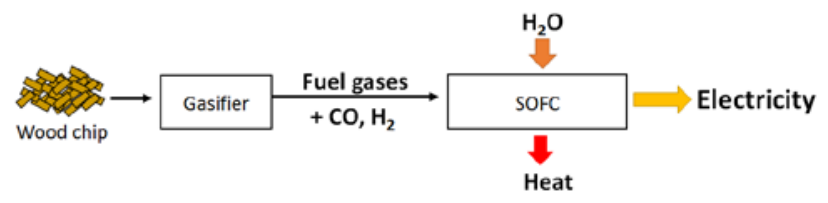

Fig. 5: Biomass gasification process with SOFC system.

In order to optimize the operation parameters, such as temperature, gasifying agent and residence time and in the gasifier, a better understanding the tar formation at molecular level is crucially important. Thus, further research should address a computational approach based on a detailed chemical kinetic model (DCKM), which can elucidate the tar formation mechanism and predict gas quality at molecular level. ${ }^{23)-25)}$ However, the DCKM is not sufficient to describe full phenomena caused by biomass gasification because of the lack of a kinetic database on the thermal decomposition processes of several heavy aromatic compounds. In order to improve the DCKM, future computational work should estimate these kinetic parameters based on ab-initio calculation and transition state theory. ${ }^{26)}$ In addition, Japanese government needs to boost the R\&D funding relating to the computational research.

In terms of economical viewpoints, we must consider strategies of expanding biomass utilization without feed-in tariff (FIT), which have been proven to make electric power companies purchase electricity from renewable energies at a price of 40 yen/kWh. ${ }^{27)}$ In 2005 the installed electrical capacity for biomass power generation was $2.2 \mathrm{GW}^{28)}$ After the introduction of FIT in 2012, the capacity has been increased and will probably reach to $3.33 \mathrm{GW}$ by $2020 .^{28)}$ In order to expand biomass utilization even after the termination of FIT, the cost of hydrogen storage systems and fuel cells should be reduced through the R\&D.

\section{Conclusion}

In conclusion, we investigated current situation of biomass gasification plants in 5 cities (c.a. Murayama City, Chichibu City, Ueno Village, Oshu City and Yamaguchi City). Although in Chichibu city the biomass gasification plant has already been stopped, the gasification plants with CHP in Murayama city, Ueno village, Yamaguchi city and Oshu city were successfully operated. These four cities have commonly promoted the efficient heat utilization such as snow melting, drying the wood and supplying hot water into mushroom bed and hot spring. However, heat loss is generated during the transportation, thus heat utilization is limited to the surrounding area. In order to obtain energy forms suitable for the long-distance transportation such as hydrogen gas and electricity, biomass gasification with hydrogen production or SOFC should be promoted in the future. Improving the gas quality is an important step towards the commercialization of these two technologies.

\section{Acknowledgement}

The author is grateful for financial support provided by the Kyushu University Advanced Graduate Program in Global Strategy for Green Asia.

\section{References}

1) Home page of International Energy

Agency: http:/www.worldenergyoutlook.org/

(Accessed 2016/06/08).

2) H. Akamine, M. Mitsuhara, M. Nishida,

"Developments of Coal-Fired Power Plants:

Microscopy Study of Fe-Ni Based Heat-Resistant

Alloy for Efficiency Improvement”, Evergreen 3,

45-53 (2016).

3) Home page of International Energy Agency: 
https://www.iea.org/topics/renewables/subtopics/bioe nergy/ (Accessed 2016/07/23).

4) P. McKendry, "Energy production from biomass (part 2): conversion technologies”, Bioresource Technology. 83 47-54 (2012).

5) T. Nussbaumer," Combustion and Co-combustion of Biomass: Fundamentals, Technologies, and Primary Measures for Emission Reduction”, Energy and Fuels 17, 1510-1521 (2003).

6) P. McKendry, "Energy production from biomass (part 1): Overview of biomass”, Bioresour. Technol., 83, 37-46 (2002).

7) S. N. Naik, V. V. Goud, P. K. Rout, A.K. Dalai, "Production of first and second generation biofuels: A comprehensive review”, Renew. Sustain. Energy Rev. 14, 578-597 (2010).

8) A. Murugesan, C. Umarani, R. Subramanian, N. Nedunchezhian, "Bio-diesel as an alternative fuel for diesel engines-A review”, Renew Sustain. Energy Rev. 13, 653-662 (2009).

9) Y. Matsumura, S.Y. Yokoyama, "Current situation and prospect of biomass utilization in Japan”, Biomass and Bioenergy 29, 304-309 (2005). doi:10.1016/j.biombioe.2004.06.011.

10) Energy Data and Modelling Center, ed. Handbook of energy and economics statistics in Japan, Tokyo, Japan: Energy Conservation Center; p. 20 (2001).

11) K. Yagi, T. Nakata, "Economic analysis on small-scale forest biomass gasification considering geographical resources distribution and technical characteristics”, Biomass and Bioenergy. 35, 2883-2892 (2011).

12) NEDO, Report of Renewable Energy (Biomass energy), p. 41 in Chap. 4: http://www.nedo.go.jp/content/100544819.pdf (Accessed 2017/02/13).

13) Report of Biomass Gasification Plants in Murayama City: http://www.chukai.ne.jp/ npo-forest-a-j/34-3.pdf (Accessed 2017/02/13).

14) Concept of Biomass Town in Murayama City: http://www.city.murayama.lg.jp/kurashi/shizen/kanky ohozen/baiomasutown.html_(Accessed 2017/02/15).

15) Home page: http://www.tsk-g.co.jp/news/pdf/070201.pdf (Accessed 2017/02/15).

16) M. Kumasaki, "Netsuden kyokyu sisutemudehajimeru mokushitsu baiomass” (in Japanese), Nikkan Kogyo Shinbun, Tokyo (2016).

17) Home page: http://www.apec-vc.or.jp/j/modules/tinyd00/?id=85\& kh_open_cid_00=3 (Accessed 2017/02/17).

18) Home page: https://www.yanmar.com/jp/news/2010/07/13/783.ht ml_(Accessed 2017/02/18).

19) Home page: https://www.ace.or.jp/web/introductory/images/20130 525111038_2.pdf_(Accessed 2017/02/19).

20) M. Ni, D.Y.C. Leung, M.K.H. Leung, K. Sumathy, "An overview of hydrogen production from biomass", Fuel Processing Technology 87, 461-472 (2006).

21) G. Marbán, T. Valdés-Solís, “Towards the hydrogen economy?”, Int. J. Hydrogen Energ. 32, 1625-1637 (2007).

22) J. Ahrenfeldt, T.P. Thomsen, U. Henriksen, L.R. Clausen, "Biomass gasification cogeneration - A review of state of the art technology and near future perspectives”, Appl. Therm. Eng. 50, 1407-1417 (2013).

23) H. M. Yang, S. Appari, S. Kudo, J. I. Hayashi, K. Norinaga, "Detailed Chemical Kinetic Modeling of Vapor-Phase Reactions of Volatiles Derived from Fast Pyrolysis of Lignin”, Ind. Eng. Chem. Res. 54, 6855-6864 (2015).

24) N. Thimthong, S. Appari, R. Tanaka, K. Iwanaga, S. Kudo, J. I. Hayashi, T. Shoji, K. Norinaga, "Kinetic Modeling of Non-Catalytic Partial Oxidation of Nascent Volatiles Derived from Fast Pyrolysis of Woody Biomass with Detailed Chemistry”, Fuel Process. Technol. 134, 159-167 (2015).

25) K. Norinaga, H. Yang, R. Tanaka, S. Appari, K. Iwanaga, Y. Takashima, S. Kudo, T. Shoji, J. I. Hayashi, "A Mechanistic Study on the Reaction Pathways Leading to Benzene and Naphthalene in Cellulose Vapor Phase Cracking”, Biomass and Bioenergy 69, 144-154 (2014).

26) Y. Furutani, S. Kudo, J. I. Hayashi, K. Norinaga, "Theoretical Study on Reaction Pathways Leading to CO and CO2 in the Pyrolysis of Resorcinol”, J. Phys. Chem. A. 121, 631-637 (2017).

27) Home page of Feed-in Tariff Scheme: http://www.enecho.meti.go.jp/category/saving_and_ne w/saiene/kaitori/kakaku.html (Accessed 2017/09/28).

28) Home page of the Feed-in Tariff Scheme for Renewable Energy:

http://www.meti.go.jp/english/policy/energy_environ ment/renewable/pdf/fit20100804b.pdf (Accessed 2017/09/28). 